\title{
PENGARUH PENGGUNAAN SMARTPHONE DAN E-LEARNING TERHADAP MOTIVASI BELAJAR SISWA PADA MATA PELAJARAN KEARSIPAN KELAS X OTKP DI SMKS KRIAN 2 SIDOARJO
}

\author{
Lussy Heavyndah ${ }^{1}$, Durinda Puspasari ${ }^{2}$ \\ 1,2 Universitas Negeri Surabaya, Surabaya, Indonesia \\ ${ }^{1}$ lussy.17080314030@mhs.unesa.ac.id, ${ }^{2}$ durindapuspasari@unesa.ac.id
}

\begin{abstract}
ABSTRAK
Tujuan penelitian ini yaitu untuk menganalisis: 1) pengaruh penggunaan smartphone terhadap motivasi belajar siswa; 2) pengaruh penggunaan $e$ learning terhadap motivasi belajar siswa; 3 ) pengaruh penggunaan smartphone dan penggunaan $e$-learning terhadap motvasi belajar siswa pada mata pelajaran kearsipan kelas X OTKP di SMKS Krian 2 Sidoarjo. Penelitian ini merupakan penelitian kuantitatif, dengan menggunakan populasi seluruh siswa kelas X OTKP SMKS Krian 2 Sidoarjo yang berjumlah 86 siswa. Sampel yang digunakan non-probability sampling dengan jenis sampel total, dimana jumlah sampel yang digunakan sama dengan jumlah populasi yaitu 86 siswa kelas X OTKP SMKS Krian 2 Sidoarjo. Teknik pengumpulan data yang digunakan yaitu wawancara dan angket. Uji coba instrumen dalam penelitian ini terdiri dari uji validitas dan uji reliabilitas. Teknik analisis data yang digunakan dalam penelitian ini yaitu: 1) uji asumsi klasik yang terdiri dari uji normalitas, uji multikolinieritas, dan uji heteroskedastisitas; 2) uji hipotesis menggunakan regresi linier berganda. Hasil penelitian menunjukkan bahwa: 1) tidak terdapat pengaruh signifikan penggunaan smartphone terhadap motivasi belajar siswa; 2) terdapat pengaruh signifikan penggunaan $e$-learning terhadap motivasi belajar siswa; 3 ) terdapat pengaruh signifikan penggunaan smartphone dan penggunaan e-learning terhadap motivasi belajar siswa pada mata pelajaran kearsipan kelas X OTKP di SMKS Krian 2 Sidoarjo.
\end{abstract}

Kata Kunci: motivasi belajar, penggunaan e-learning, penggunaan smartphone

\section{THE EFFECT OF SMARTPHONE AND E-LEARNING ON STUDENTS' LEARNING MOTIVATION IN THE RECORD MANAGEMENT SUBJECT AT GRADE X OTKP OF SMKS KRIAN 2 SIDOARJO}

\begin{abstract}
The purposes of this research were to analyze the effect of smartphones on students' learning motivation, the effect of e-learning on students' learning motivation, and the effect of smartphones and e-learning on students' learning motivation in the record management subject at grade $X$ OTKP of SMKS Krian 2 Sidoarjo. It was quantitative research, in which the samples were chosen through non-probability sampling with total sample type. The total population of 86 students at grade X OTKP of SMKS Krian 2 Sidoarjo were chosen as the samples. The instruments in this research were interviews and questionnaires. The instruments were tested for their validity and reliability. After that, the data were analyzed by: 1) classic assumption test consisting of normality test, multicollinearity test, and heteroscedasticity test; 2) hypothesis testing using multiple linear regression. The results showed that smartphones did not have a significant effect on students' learning motivation while e-learning had a significant effect on students' learning motivation. Overall, smartphones and e-learning significantly affected students' learning motivation in the recording management subject at grade $X$ OTKP of SMKS Krian 2 Sidoarjo.
\end{abstract}

Keywords: learning motivation, e-learning, smartphone

\begin{tabular}{|c|c|c|}
\hline Submitted & Accepted & Published \\
\hline 24 Mei 2021 & 01 November 2021 & 24 November 2021 \\
\hline
\end{tabular}

\begin{tabular}{|l|c|c|}
\hline Citation & $:$ & $\begin{array}{r}\text { Heavyndah, L., \& Puspasari, D. (2021). Pengaruh Penggunaan Smartphone dan E-Learning Terhadap Motivasi Belajar } \\
\text { Siswa Pada Mata Pelajaran Kearsipan Kelas X Otkp Di Smks Krian 2 Sidoarjo. Jurnal PAJAR (Pendidikan dan } \\
\text { Pengajaran), 5(6), 1588-1603. DOI : http://dx.doi.org/10.33578/pjr.v5i6.8421. }\end{array}$ \\
\hline
\end{tabular}

\section{PENDAHULUAN}

Pendidikan adalah salah satu aspek penting dalam upaya meningkatkan kualitas sumber daya manusia melalui pengajaran secara formal. Pendidikan merupakan sebuah proses

yang dilakukan secara terprogram untuk mengembangkan potensi serta ilmu pengetahuan seorang siswa dalam menempuh sebuah pembelajaran. Pembelajaran yang efektif tentunya 
akan menunjang proses kegiatan belajar. Belajar adalah salah satu kegiatan yang dilakukan oleh seorang peserta didik untuk mencari dan mengetahui ilmu pengetahuan, keterampilan, sikap dan perilaku yang didapat dari sebuah pengalaman. Keinginan seseorang untuk memulai belajar adalah langkah awal dalam menempuh pendidikannya. Salah satu faktor yang menjadikan seseorang untuk ingin memulai kegiatan belajar adalah melalui motivasi. Motivasi merupakan sebuah dorongan baik berasal dari dalam diri seseorang maupun dari pengaruh lingkungan luar yang mengarahkan seseorang dalam melakukan aktivitas untuk mencapai suatu tujuan. Menurut Aurora \& Effendi (2019), motivasi merupakan sebuah dorongan dalam diri yang mampu meningkatkan minat untuk melakukan sesuatu. Narpati, Handayani \& Bukhari (2019) berpendapat bahwa motivasi adalah interaksi seseorang terhadap situasi yang mendukungnya yang menimbulkan adanya dorongan untuk melakukan sesuatu tergantung pada waktu yang tepat pula. Motivasi memiliki dampak bagi seseorang salah satunya dalam kegiatan belajar, dimana dapat diartikan bahwa motivasi belajar merupakan dorongan yang ada dalam diri seorang peserta didik yang akan memberikan arah dalam kegiatan belajar. Seseorang yang memiliki motivasi belajar dapat diketahui melalui sikap yang menunjukkan semangat dalam belajar dan lebih bersemangat untuk mencapai prestasi yang terbaik. Begitupun sebaliknya, apabila seseorang tidak memiliki motivasi belajar maka akan cenderung untuk bermalas-malasan dan tidak memiliki semangat untuk mencapai prestasi yang terbaik dalam belajar. Motivasi belajar dapat didukung dengan adanya perkembangan dari teknologi yang memadai.

Perkembangan teknologi saat ini semakin berkembang pesat. Adanya perkembangan teknologi seharusnya dapat membangkitkan motivasi dalam belajar karena dengan hal tersebut peserta didik terbantu dengan kecanggihan teknologi salah satunya melalui smartphone. Smartphone merupakan salah satu bentuk kecanggihan teknologi yang dapat dimiliki oleh semua masyarakat. Perkembangan smartphone terlihat sudah mengglobal salah satunya dalam lingkup pendidikan, dimana pendidikan memegang peran penting dalam pengembangan kualitas sumber daya manusia melalui sebuah pengajaran dengan mengikuti perkembangan teknologi yang dapat diterapkan dalam proses pembelajaran, sehingga terciptanya sumber daya manusia yang berkualitas dan up to date sesuai dengan perkembangan zaman generasi millenial. Menurut Larasati \& Nikmah (2020), penggunaan smartphone sangat ditunjang oleh kemudahan dalam mengakses fitur-fitur yang ada. Internet merupakan penunjang utama dalam penggunaan smartphone, dimana jika dikaitkan dalam bidang pendidikan internet merupakan terobosan dalam membantu kegiatan belajar dan mengajar. Khaeriyah \& Mahmud (2017) berpendapat bahwa dengan menggunakan smartphone peserta didik dapat aktif di jejaring sosial karena terdapat banyak fitur yang memfasilitasi para penggunanya untuk terhubung dengan internet lebih mudah dan dapat dilakukan kapan saja dan dimana saja. Hasil penelitiannya juga menyatakan bahwa intensitas penggunaan smartphone berpengaruh secara positif dan signifikan terhadap motivasi belajar peserta didik kelas XI IPS SMA Negeri di Pemalang Kota. Smith, et al (2019) menyampaikan bahwa smartphone dapat membantu dalam pembelajaran dan tidak mengurangi motivasi belajar peserta didik. Maknuni (2020) dalam penelitiannya mengungkapkan bahwa media belajar smartphone sangat berpengaruh dalam proses belajar mengajar di era pandemi dan merupakan salah satu media yang efektif untuk belajar jarak jauh.

Menjelang pertengahan tahun 2020 eksistensi dunia pendidikan sangat lemah dikarenakan adanya wabah yang merambah begitu cepat dan mengakibatkan terjadinya pandemi sehingga menyebabkan kondisi lingkungan pembelajaran tidak dapat dilakukan seperti biasanya secara tatap muka. Kondisi tersebut menyebabkan adanya tuntutan dalam pemanfaatan kecanggihan teknologi baik melalui smartphone, laptop, komputer ataupun barang yang mudah membantu dalam melakukan komunikasi pembelajaran jarak jauh atau biasanya disebut dengan pembelajaran online atau daring. Pembelajaran daring atau dalam jaringan dapat diterapkan menggunakan e-learning, yang merupakan sebuah pembelajaran elektronik yang 
memiliki fungsi untuk membantu memudahkan jalannya proses kegiatan belajar mengajar yang dilakukan oleh guru dengan peserta didik. Menurut Aurora \& Effendi (2019), e-learning merupakan sebuah teknologi baru yang membuat modifikasi dalam proses pembelajaran sehingga dengan menggunakan e-learning dapat memiliki pengetahuan dasar tentang teknologi yang sangat berguna untuk mencapai sebuah tujuan dalam pendidikan. Sujiwo \& A'yun (2020) dalam penelitiannya menyatakan bahwa terdapat hubungan yang positif antara pembelajaran $e$ learning dengan motivasi belajar mahasiswa. Penelitian Aini, Dhaniarti \& Khoirunisa (2019) menjelaskan bahwa penggunaan e-learning pada situs web berbasis sistem manajemen konten dapat meningkatkan motivasi belajar peserta didik karena dapat digunakan secara efektif dan efisien saat pembelajaran. Hasil penelitian Dalimunthe (2020) juga mengungkapkan bahwa terdapat pengaruh yang positif dan signifikan antara penggunaan media pembelajaran e-learning sebagai variabel bebas dengan motivasi belajar mahasiswa sebagai variabel terikat.

Sekolah Menengah Kejuruan Swasta atau SMKS merupakan sekolah tingkatan menengah ke atas yang lebih mengarah ke kejuruan salah satunya yaitu SMKS Krian 2 Sidoarjo yang berlokasi di daerah Krian, Sidoarjo. Sekolah tersebut telah menerapkan sistem pembelajaran online dengan memanfaatkan kecanggihan smartphone yang dimiliki oleh siswa. Sekolah menengah kejuruan ini memiliki beberapa jurusan salah satunya yaitu Otomatisasi Tata Kelola Perkantoran. Jurusan tersebut memiliki mata pelajaran yang terdapat kegiatan praktik di dalamnya seperti mata pelajaran kearsipan. Kearsipan merupakan salah satu mata pelajaran wajib yang diajarkan di SMKS Krian 2 Sidoarjo pada jurusan Otomatisasi Tata Kelola Perkantoran. Mata pelajaran kearsipan termasuk salah satu mata pelajaran yang pembahasannya dominan menggunakan praktik yang diajarkan selama satu tahun pada kelas X. Materi yang ada dalam kearsipan meliputi tata cara menyimpan arsip dengan menggunakan lima sistem, yaitu sistem abjad, sistem subjek, sistem wilayah, sistem tanggal, dan sistem nomor.
Hasil studi pendahuluan melalui wawancara dengan guru mata pelajaran kearsipan di SMKS Krian 2 Sidoarjo bahwa semua peserta didik sudah memiliki dan menggunakan smartphone, namun masih terdapat kendala yang dialami seperti kurangnya kapasitas penyimpanan pada smartphone sehingga tidak dapat menyimpan file lebih banyak maupun tidak bisa mengunduh aplikasi yang diperlukan dalam pembelajaran. Berdasarkan kendala tersebut pihak sekolah mampu memahami kondisi yang dirasakan setiap siswa, namun siswa juga tidak menyerah dan tetap semangat serta selalu berusaha dalam meminimalisir kendala yang mereka hadapi. SMKS Krian 2 Sidoarjo merupakan salah satu sekolah yang juga telah menerapkan pembelajaran daring dengan menggunakan berbagai akses $e$ learning yang memudahkan guru dan siswa agar dapat melangsungkan proses pembelajaran. Terdapat beberapa kendala dalam menerapkan $e$ learning seperti terkendalanya sinyal sehingga menghambat proses pembelajaran, respon siswa yang kurang antusias pada saat pembelajaran berlangsung dikarenakan kurangnya pemantauan dari guru secara maksimal sehingga guru tidak dapat mengetahui apa yang sedang dilakukan siswa pada saat pembelajaran berlangsung. Dari kendala tersebut, pihak sekolah tetap berusaha semaksimal mungkin dalam pemanfaatan media pembelajaran melalui e-learning yang digunakan seperti whatsapp, edmodo, google classroom maupun platform e-learning lainnya yang digunakan di SMKS Krian 2 Sidoarjo khususnya pada jurusan Otomatisasi Tata Kelola Perkantoran. Sehubungan dengan kedua hal tersebut mempengaruhi motivasi belajar siswa seperti pemahaman materi tidak maksimal terutama pada mata pelajaran kearsipan yang di dalamnya terdapat praktik sehingga mempengaruhi guru dalam memberikan penugasan kepada siswa.

Adapun tujuan dalam penelitian ini di antaranya untuk menganalisis: 1) pengaruh penggunaan smartphone terhadap motivasi belajar siswa pada mata pelajaran kearsipan kelas $\mathrm{X}$ OTKP di SMKS Krian 2 Sidoarjo; 2) pengaruh penggunaan e-learning terhadap motivasi belajar siswa pada mata pelajaran kearsipan kelas $\mathrm{X}$ OTKP di SMKS Krian 2 Sidoarjo; 3) pengaruh 
penggunaan smartphone dan penggunaan $e$ learning terhadap motivasi belajar siswa pada mata pelajaran kearsipan kelas X OTKP di SMKS Krian 2 Sidoarjo.

\section{KAJIAN TEORETIS}

\section{Belajar dan Pembelajaran}

Belajar merupakan suatu sistem yang termuat dalam proses pembelajaran dan pembelajaran terdiri dari beberapa komponen yang saling berinteraksi satu sama lain, terdiri dari guru, peserta didik, tujuan, materi, media, metode dan evaluasi (Pane \& Dasopang, 2017). Hanafy (2014) menjelaskan bahwa belajar merupakan aktivitas baik fisik maupun psikis yang menghasilkan perubahan tingkah laku yang baru pada diri individu untuk belajar dalam bentuk kemampuan yang bersifat konstan dan bukan disebabkan oleh sesuatu yang bersifat sementara. Menurut Setiawan (2017), belajar adalah suatu proses aktivitas mental yang dilakukan seseorang untuk memperoleh suatu perubahan tingkah laku yang bersifat positif dan menetap relatif lama melalui latihan atau pengalaman yang menyangkut aspek kepribadian baik secara fisik ataupun psikis. Berdasarkan penjelasan di atas maka belajar adalah kegiatan baik fisik maupun psikis yang dilakukan seseorang untuk mengembangkan potensinya.

Menurut Festiawan (2020), pembelajaran adalah upaya yang dilakukan dengan sengaja oleh seorang guru untuk menyampaikan ilmu pengetahuan, mengorganisasi serta menciptakan sistem lingkungan dengan berbagai metode sehingga siswa dapat melakukan kegiatan belajar secara efektif dan efisien dengan hasil yang optimal. Menurut Anurrahman (2014), pembelajaran merupakan upaya memberikan masukan kepada siswa yang belum terdidik menjadi siswa yang terdidik, siswa yang belum memiliki pengetahuan menjadi siswa yang memiliki pengetahuan dan siswa dengan sikap yang belum mencerminkan diri pribadi positif menjadi siswa yang bersikap dan memiliki tingkah laku yang lebih baik. Perlunya pembelajaran yang interaktif, inspiratif dan menyenangkan harus mampu dilaksanakan agar peserta didik termotivasi sehingga mampu berpartisipasi aktif dalam pembelajaran (Rikizaputra \& Sulastri, 2020). Sehingga pembelajaran merupakan upaya yang dilakukan seorang guru untuk membantu peserta didik dalam kegiatan belajar dengan hasil yang maksimal.

\section{Motivasi Belajar}

Menurut Sujiwo \& A'yun (2020), motivasi merupakan sesuatu hal yang dapat menyebabkan seseorang melakukan tindakan atau perilaku untuk mencapai tujuan yang diharapkan. Motivasi dalam belajar sangat dibutuhkan bagi peserta didik dalam proses belajar. Karena adanya dorongan yang timbul baik secara internal maupun eksternal akan mempengaruhi kekuatan dalam proses belajar. Fitria, Saifudin, \& Zaman (2020) mengungkapkan bahwa motivasi belajar bersifat pribadi, dimana seseorang yang memiliki motivasi belajar yang tinggi mampu menjadikan dari yang tadinya tidak mampu menjadi mampu dan tidak bisa menjadi bisa. Penelitian Harandi (2015) mengungkapkan bahwa motivasi peserta didik terbagi menjadi dua yaitu motivasi intrinsik dan motivasi ekstrinsik, dimana motivasi intrinsik melibatkan diri mereka sendiri dalam belajar sehingga peserta didik memiliki serta menggunakan strategi yang lebih kuat untuk membimbing diri mereka sendiri, sedangkan motivasi ekstrinsik cenderung memiliki pengaruh yang sedikit daripada motivasi dari diri mereka sendiri. Dalam penelitian Hamidah, dkk (2020) juga mengungkapkan bahwa motivasi belajar adalah faktor yang mempengaruhi prestasi belajar apabila dilihat dari sudut pandang internal, sedangkan guru sebagai sudut pandang eksternal karena guru adalah faktor yang mempengaruhi prestasi belajar. Berdasarkan beberapa pendapat di atas dapat disimpulkan bahwa motivasi belajar merupakan dorongan yang timbul dalam diri siswa maupun pengaruh positif dari orang lain untuk melakukan kegiatan belajar sehingga tujuan dari belajar dapat tercapai secara optimal.

Adapun indikator motivasi belajar yang digunakan dalam penelitian ini menurut Kuswinarko \& Kusumah (2017) diantaranya, indikator motivasi intrinsik meliputi: 1) tantangan, adanya sebuah target berkaitan dengan pembelajaran yang harus diselesaikan; 2) keingintahuan, rasa ingin tahu akan muncul apabila guru memberikan clue mengenai pelajaran sehingga siswa termotivasi untuk bertanya; 3 ) 
kontrol dan fantasi, adanya pengontrolan melalui hasil atau prestasi belajar agar siswa dapat termotivasi dan mampu melibatkan siswa untuk berimajinasi dalam kegiatan simulasi atau games yang mampu membuat siswa lebih paham dalam pembelajaran. Sedangkan indikator motivasi ekstrinsik meliputi: 1) mendapat hadiah, pemberian penghargaan sebagai sikap apresiasi; 2) menerima pujian dari guru, mendengar ucapan yang positif mampu membangkitkan motivasi pada diri siswa; 3) terhindar dari hukuman, adanya contoh sikap yang positif agar dapat dicontoh dengan baik oleh siswa sehingga meminimalisir hukuman yang akan terjadi.

\section{Penggunaan Smartphone}

Teknologi menjadi terobosan utama dalam membantu aktivitas kehidupan, seperti lebih memudahkan untuk mendapat informasi secara cepat dan efisien. Smartphone menjadi salah satu bentuk dari kecanggihan teknologi saat ini. Telah diketahui bahwa smartphone sangat dibutuhkan oleh masyarakat secara umum guna membantu memudahkan tujuan dari pekerjaan ataupun sesuai dengan kebutuhan personal. Tidak hanya untuk kalangan secara umum, smartphone juga sangat diperlukan dalam bidang pendidikan. Khaeriyah \& Mahmud (2017) mengungkapkan bahwa dengan menggunakan smartphone peserta didik dapat aktif di media sosial dengan mudah karena smartphone memiliki banyak fitur yang memfasilitasi penggunanya untuk terhubung dengan internet secara mudah kapan saja dan di mana saja. Adjei (2019) dalam penelitiannya menyatakan bahwa smartphone bisa diakses di manapun dan kapanpun seperti pada saat di mobil, kereta, pesawat, maupun tempat lainnya sehingga sangat memudahkan untuk diakses terutama dalam mengakses pembelajaran. Dalam proses pembelajaran, smartphone digunakan sebagai perantara untuk pembelajaran jarak jauh dengan menggunakan akses internet yang dilengkapi berbagai aplikasi maupun media pembelajaran berbasis online yang memudahkan komunikasi antara pendidik dan peserta didik dapat berlangsung secara optimal. Menurut Thohuroh \& Puspasari (2018), media pembelajaran yang menarik akan membuat siswa lebih terangsang untuk aktif dalam mengembangkan pengetahuannya sendiri terhadap materi yang telah disampaikan sehingga dapat membantu siswa untuk lebih bisa memahami materi pembelajaran. Sehingga dari beberapa penjelasan tersebut dapat disimpulkan bahwa smartphone merupakan salah satu media pembelajaran berupa alat elektronik yang memiliki berbagai fitur-fitur yang mendukung untuk memudahkan penggunanya dalam mengakses informasi secara efektif dan efisien.

Adapun indikator penggunaan smartphone yang digunakan dalam penelitian ini menurut Etnanta \& Irhandayaningsih (2017) diantaranya: 1) mempunyai perasaan senang saat membaca menggunakan smartphone, dimana timbulnya rasa senang akan membuat rasa nyaman pada saat menggunakan smartphone terutama dalam hal pembelajaran; 2) memusatkan perhatian saat membaca menggunakan smartphone, perlunya konsentrasi dalam pemanfaatan smartphone pada saat pembelajaran agar pemahaman bisa didapatkan; 3) memiliki motivasi untuk membaca menggunakan smartphone, hal tersebut bisa mengembangkan budaya literasi digital terutama pada saat pembelajaran; 4) penggunaan waktu untuk membaca menggunakan smartphone, perlunya manajemen waktu dalam penggunaan smartphone agar tidak menimbulkan rasa ketergantungan yang tinggi; dan 5) mempunyai emosi saat membaca menggunakan smartphone, yang merupakan adanya pengukuran tingkat emosional yang terjadi apabila ketergantungan menggunakan smartphone.

\section{Penggunaan E-Learning}

Berkembangnya sebuah teknologi mempengaruhi perubahan aktivitas yang dilakukan setiap hari salah satunya dalam ranah pendidikan mengenai pembelajaran. Adanya suatu teknologi yang mengembangkan sebuah pembelajaran sehingga membantu dilakukannya proses belajar mengajar secara canggih, efektif dan efisien. Pengembangan pembelajaran yang dimasud adalah e-learning. Dalam penelitian Rikizaputra \& Sulastri (2020), e-learning merupakan pendekatan pembelajaran atau pembelajaran melalui pemanfaatan pendekatan teknologi komputer dan internet. E-learning dapat berupa website, aplikasi maupun media pembelajaran lainnya yang berbasis online. Aurora \& Effendi (2019) mengatakan 
bahwa e-learning merupakan bentuk inovasi dari proses belajar yang didesain dengan baik, lebih terpusat pada pengguna dan lebih interaktif yang memiliki berbagai kemudahan bagi pengguna karena dapat diakses kapan saja dan di mana saja. Penggunaan e-learning dapat meningkatkan kualitas pendidikan karena fakta membuktikan bahwa penggunaan elemen pembelajaran dan teknologi pendidikan jarak jauh mampu meningkatkan siswa dalam penguasaan materi secara mandiri (Sandybayev, 2020). Menurut Paramita \& Puspasari (2018), yang dimaksud dengan media pembelajaran adalah segala sesuatu yang dapat digunakan dalam proses belajar mengajar untuk menyampaikan pesan dari pendidik kepada peserta didik untuk merangsang keinginan belajar siswa sehingga terjadi proses belajar mengajar yang sesuai dengan tujuan dalam pembelajaran. Berdasarkan penjelasan tersebut, dapat disimpulkan bahwa e-learning merupakan sebuah media pembelajaran elektronik yang telah didesain dalam bentuk teknologi informasi dan komunikasi dimana penerapannya dilakukan dalam bidang pendidikan yang memberikan kemudahan baik untuk pendidik maupun siswa dalam penerapan proses pembelajaran secara digital.

Adapun indikator penggunaan $e$-learning yang digunakan dalam penelitian ini menurut Jayatri, Ayuningtyas, \& Andriyani (2019) diantaranya: 1) frekuensi penggunaan, dimana dapat mengetahui sering atau tidaknya untuk siswa dalam menggunakan e-learning; 2) motivasi penggunaan, adanya motivasi yang terarah untuk menggunakan e-learning dalam proses pembelajaran; 3) arah sikap atau kesiapan penggunaan, dimana adanya sikap yang positif untuk mengetahui kesiapan dalam menggunakan $e$ learning; 4) minat atau ketertarikan penggunaan $e$ learning, adanya ketertarikan peserta didik selama menggunakan e-learning saat proses pembelajaran karena terdapat makna ketika menggunakannnya. Hipotesis dalam penelitian ini sebagai berikut:

\section{Hubungan Penggunaan Smartphone dengan Motivasi Belajar Siswa}

Berdasarkan penelitian yang dilakukan oleh Ardyansyah (2019) mengungkapkan bahwa adanya pengaruh penggunaan smartphone terhadap motivasi belajar mahasiswa program studi teknik informatika di ITN. Puasanti \& Shanti (2019) menyatakan bahwa terdapat hubungan yang positif antara intensitas penggunaan smartphone dengan motivasi belajar siswa SMK Tunas Harapan Pati. Penelitian Mintarsih (2020) menyebutkan bahwa pembelajaran dengan pemanfaatan aplikasi Quizizz berbasis smartphone dapat berpengaruh positif terhadap peningkatan motivasi belajar siswa. Smith, et al (2019) juga mengatakan bahwa smartphone berpengaruh terhadap motivasi belajar siswa. Adapun penelitian Frafitasari (2018) menjelaskan bahwa adanya hubungan antara penggunaan smartphone dengan motivasi belajar pada mahasiswa kebidanan semester 5 di Stikes Surya Mitra Husada Kediri. Dari beberapa hasil penelitian tersebut maka dapat dirumuskan hipotesis sebagai berikut:

$\mathrm{H}_{1}$ : Terdapat pengaruh signifikan penggunaan smartphone terhadap motivasi belajar siswa pada mata pelajaran kearsipan kelas X OTKP di SMKS Krian 2 Sidoarjo

\section{Hubungan Penggunaan E-learning dengan Motivasi Belajar Siswa}

Penelitian yang dilakukan Sandybayev (2020) mengutarakan bahwa implementasi penggunaan e-learning mampu meningkatkan motivasi belajar dan sebagai hasilnya akan mengarah kepada hasil belajar yang lebih baik. Penelitian Srinadi (2015) mengungkapkan bahwa penggunaan internet yang digunakan sebagai media pembelajaran dapat berpengaruh positif terhadap motivasi belajar siswa. Rikizaputra \& Sulastri (2020) dalam penelitiannya menunjukkan bahwa terdapat pengaruh e-learning dengan google classroom terhadap hasil belajar dan motivasi belajar siswa pada materi sistem pencernaan. Adapun penelitian dari Mahmud \& Iqbal (2019) menyatakan bahwa adanya pengaruh yang signifikan dalam pembelajaran edmodo terhadap motivasi belajar siswa di SMKN 1 Palopo. Hikmawan \& Sarino (2018) juga menyatakan bahwa adanya pengaruh yang signifikan antara media pembelajaran berbasis edmodo terhadap motivasi belajar siswa di SMK Swasta Kota Bekasi. Berdasarkan dari hasil penelitian tersebut maka dapat dirumuskan hipotesis sebagai berikut: 
$\mathrm{H}_{2}$ : Terdapat pengaruh signifikan penggunaan $e$ learning terhadap motivasi belajar siswa pada mata pelajaran kearsipan kelas X OTKP di SMKS Krian 2 Sidoarjo

\section{Hubungan Penggunaan Smartphone dan Penggunaan E-learning dengan Motivasi Belajar Siswa \\ Berdasarkan penelitian yang dilakukan} Moh (2015) yang menyampaikan bahwa adanya pengaruh positif pada saat pembelajaran menggunakan smartphone dan mobile learning terhadap motivasi belajar. Khaeriyah \& Mahmud (2017) mengatakan bahwa intensitas penggunaan smartphone dan pemanfaatan internet sebagai sumber belajar berpengaruh secara positif dan signifikan terhadap motivasi belajar siswa. Muskita (2018) dalam penelitiannya mengungkapkan bahwa pemanfaatan internet menggunakan media handphone dapat berpengaruh signifikan terhadap motivasi belajar mahasiswa baru. Penelitian Riyanti \& Rusdi (2018) menyatakan bahwa smartphone juga bisa diterapkan melalui aplikasi mobile game based learning dan hasil penelitian menunjukkan bahwa penggunaan game edukasi smartphone memberikan pengaruh yang signifikan terhadap hasil belajar dan motivasi belajar mahasiswa pendidikan biologi. Selanjutnya, penelitian Larasati \& Nikmah (2020) menunjukkan bahwa penggunaan smartphone dan pemanfaatan $e$ learning secara simultan berpengaruh positif terhadap motivasi belajar pada pelaksanaan on the job training peserta didik kelas XI OTKP SMKN 10 Surabaya. Sehingga dapat dirumuskan hipotesis sebagai berikut:

$\mathrm{H}_{3}$ : Terdapat pengaruh signifikan penggunaan smartphone dan penggunaan $e$ - learning terhadap motivasi belajar siswa pada mata pelajaran kearsipan kelas X OTKP di SMKS Krian 2 Sidoarjo

\section{METODE PENELITIAN}

Penelitian ini merupakan penelitian kuantitatif dengan menggunakan metode survei. Menurut (Sugiyono, 2019), metode penelitian survei merupakan metode penelitian kuantitatif yang digunakan untuk mendapatkan data yang terjadi pada masa lampau atau saat ini, tentang keyakinan, pendapat, karakteristik, perilaku, hubungan variabel dan untuk menguji beberapa hipotesis tentang variabel sosiologis dan psikologis dari sampel yang diambil pada populasi tertentu. Teknik pengumpulan data dalam penelitian ini adalah angket dengan menggunakan skala likert dan wawancara untuk studi pendahuluan dengan menggunakan pedoman wawancara tidak terstruktur. Populasi dalam penelitian ini adalah seluruh siswa kelas X OTKP SMKS Krian 2 Sidoarjo yang berjumlah 86 peserta didik. Sampel dari populasi penelitian ditentukan dengan menggunakan teknik pengambilan sampel yaitu non probability sampling dengan jenis sampling total, dimana seluruh anggota populasi dijadikan sampel semua. Menurut Sugiyono (2019), penelitian yang dilakukan pada populasi di bawah 100 sebaiknya dilakukan dengan sensus, sehingga seluruh anggota populasi tersebut dijadikan sampel semua sebagai subyek yang dipelajari atau sebagai responden pemberi informasi. Dalam penelitian ini jumlah sampel yang digunakan sama dengan jumlah populasi yaitu 86 siswa kelas X OTKP di SMKS Krian 2 Sidoarjo. Model konseptual dalam penelitian ini dapat dilihat pada gambar 1 sebagai berikut: 


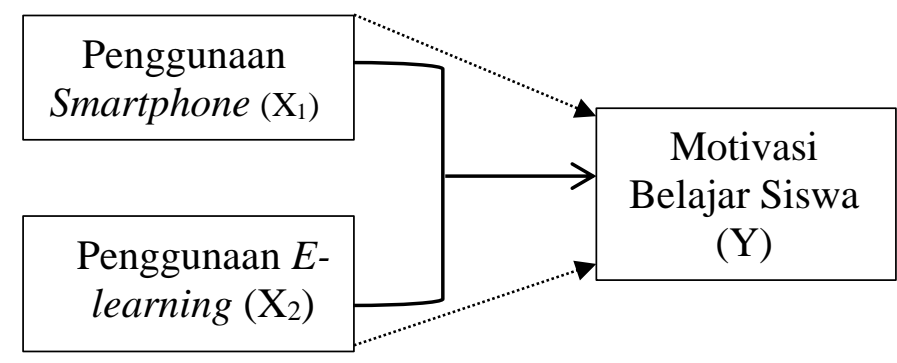

Keterangan:

Parsial

Simultan

Gambar 1. Model Konseptual Penelitian

Sumber: Data diolah oleh peneliti (2021)

Uji coba instrumen dalam penelitian ini terdiri dari: 1) uji validitas, yaitu ketepatan dan kecermatan alat ukur terhadap konsep yang diukur serta melakukan tugas sebagai fungsi ukurnya. Instrumen dapat dikatakan baik apabila mampu mengukur apa yang diinginkan dan dapat mengungkapkan data dari variabel yang diteliti secara tepat. Instrumen dikatakan valid apabila nilai $r$ hitung $>$ nilai $r$ tabel dan instrumen tidak dikatakan valid apabila nilai $r$ hitung $<\mathrm{r}$ tabel; 2) uji reliabilitas yaitu suatu uji yang bertujuan untuk mengetahui apakah alat ukur yang digunakan tepat untuk mengukur konsep yang hendak diukur dan menunjukkan pada sejauh mana suatu hasil pengukuran relatif konsisten apabila pengukuran dilakukan berulang kali. Instrumen dapat dikatakan reliabel apabila Cronbach's Alpha > 0.6 (Nurhasanah, 2017).

Teknik analisis data yang digunakan dalam penelitian ini terdiri dari: 1) Uji Asumsi Klasik yang meliputi a) Uji Normalitas, bertujuan untuk mengetahui apakah distribusi sebuah data mengikuti atau mendekati distribusi normal. Dalam uji ini dapat diketahui apakah distribusi sebuah data mengikuti atau mendekati distribusi normal. Penelitian ini menggunakan teknik uji Kolmogorov-Smirnov. Pengambilan keputusan pada pengujian ini yakni apabila nilai Asymp. Sig. (2-tailed) > 0.05 maka data berdistirbusi normal, dan apabila nilai Asymp. Sig. (2-tailed) < 0.05 maka data tidak berdistribusi normal (Nurhasanah, 2017), b) Uji Multikolinieritas, digunakan untuk mengetahui terjadinya korelasi antar variabel bebas, dengan menggunakan metode variance inflation factor (VIF). Hasil uji multikolinieritas terjadi apabila nilai VIF > 10 (Santoso, 2019), c) Uji Heteroskedastisitas, dilakukan dengan tujuan untuk menguji apakah dalam model regresi terjadi suatu ketidaksamaan variance dan residual pengamatan yang satu dengan yang lain. Uji ini dilakukan menggunakan diagram scatterplot. Pengambilan keputusan dapat diketahui apabila penyebaran titik tidak berpola atau menyebar maka tidak terjadi heteroskedastisitas dan apabila penyebaran titik berpola atau berpusat maka terjadi heteroskedastisitas (Santoso, 2019); 2) Uji hipotesis menggunakan Regresi Linier Berganda yang bertujuan untuk menganalisis apakah terdapat pengaruh penggunaan smartphone dan penggunaan e-learning terhadap motivasi belajar siswa pada mata pelajaran kearsipan kelas $\mathrm{X}$ OTKP di SMKS Krian 2 Sidoarjo baik secara parsial maupun secara simultan.

\section{HASIL DAN PEMBAHASAN}

Hasil uji coba instrumen pada penelitian ini dapat dilihat sebagai berikut:

\section{1) Uji Validitas}

Uji validatas menggunakan program SPSS 24. Terdapat 72 item pernyataan yang terdiri dari 22 item pernyataan berkaitan dengan penggunaan smartphone, 20 item pernyataan berkaitan dengan penggunaan e-learning dan 30 item pernyataan berkaitan dengan motivasi belajar. Hasil uji validitas dari 72 item pernyataan tersebut secara keseluruhan telah dinyatakan valid.

\section{2) Uji Reliabilitas}

Uji reliabilitas menggunakan program SPSS 24, dapat diketahui dari nilai Cronbach's 
Alpha, $\mathrm{X}_{1}$ sebesar $0,891>0,6 ; \mathrm{X}_{2}$ sebesar $0,957>$ 0,6 ; dan $\mathrm{Y}$ sebesar $0,965>0,6$. Maka ketiga variabel tersebut dinyatakan reliabel dan termasuk dalam kriteria reliabilitas sangat tinggi.
Hasil uji asumsi klasik pada penelitian ini dapat dilihat sebagai berikut:

1) Uji Normalitas

Tabel 1. Hasil Uji Normalitas

\begin{tabular}{c|c|c}
\hline $\begin{array}{c}\text { Asymp. Sig. (2- } \\
\text { tailed) }\end{array}$ & Kriteria & Keputusan \\
\hline 0,200 & $\begin{array}{c}\text { Asymp.Sig.(2-tailed) }> \\
0,05\end{array}$ & $\begin{array}{c}\text { Berdistribusi } \\
\text { normal }\end{array}$ \\
\hline
\end{tabular}

Sumber: Data Diolah Peneliti (2021)

Berdasarkan data pada tabel 1 diketahui nilai Asymp. Sig. (2-tailed) adalah $0.200>0.05$ yang artinya data tersebut berdistribusi normal.

2) Uji Multikolinieritas

Hasil uji multikolinieritas didapatkan dengan nilai tolerance $>0,10$ dan VIF $<10$. Hal ini dapat ditunjukkan dengan hasil nilai tolerance $0,773>0,10$ dan nilai VIF $1,294<10$. Sehingga dapat disimpulkan bahwa tidak terjadi multikolinieritas.

\section{3) Uji Heteroskedastisitas}

Uji heteroskedastisitas dilakukan menggunakan diagram scatterplot. Pengambilan keputusan dapat diketahui apabila penyebaran titik tidak berpola atau menyebar maka tidak terjadi heteroskedastisitas dan apabila penyebaran titik berpola atau berpusat maka terjadi heteroskedastisitas.

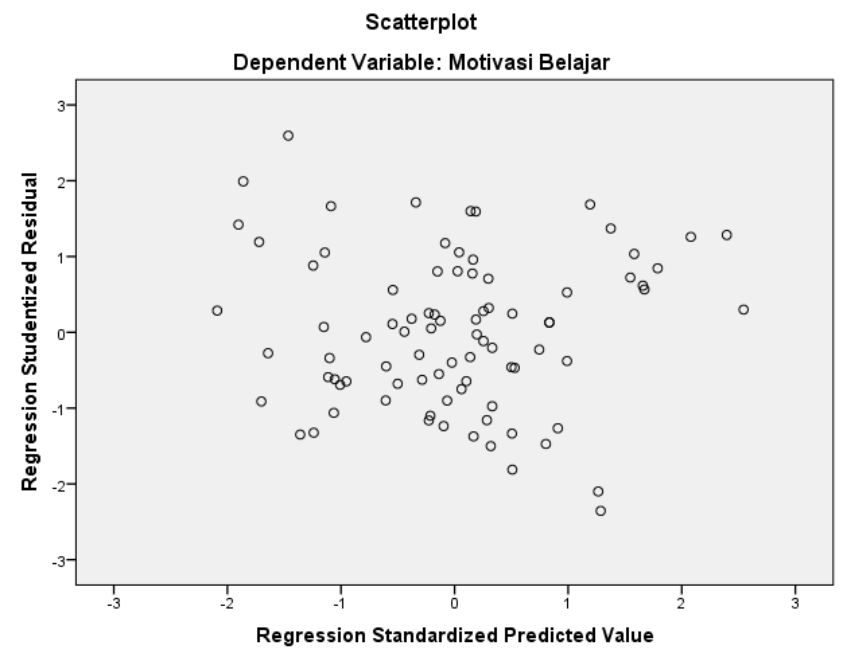

Gambar 2. Hasil Uji Heteroskedastisitas Sumber: Data Diolah Peneliti (2021)

Dalam diagram scatterplot dapat diketahui bahwa penyebaran titik tidak berpola atau menyebar sehingga dapat disimpulkan bahwa tidak terjadi heteroskedastisitas.
Uji hipotesis pada penelitian ini menggunakan uji regresi linier berganda. Hasil uji regresi linier berganda dapat ditunjukkan sebagai berikut: 
Tabel 2. Hasil Uji-t

\begin{tabular}{c|c|c|c}
\hline Variabel & Kriteria t tabel & Kiteria nilai Sig. & Keterangan \\
\hline Penggunaan Smartphone (X1) & $\mathrm{t}$ hitung $(1.275)<\mathrm{t}$ tabel $(1.988)$ & $0.206>0.05$ & Ditolak \\
Penggunaan E-Learning (X2) & $\mathrm{t}$ hitung (2.048) $>\mathrm{t}$ tabel $(1.988)$ & $0.044<0.05$ & Diterima \\
\hline \multicolumn{2}{|c|}{ Sumber: Data Diolah Peneliti (2021) }
\end{tabular}

Tabel 3. Uji F

\begin{tabular}{c|c|c}
\hline Kriteria f tabel & Kriteria nilai Sig. & Keterangan \\
\hline $5.381>3.11$ & $0.006<0.05$ & Diterima \\
\hline
\end{tabular}

Model persamaan regresi linier berganda untuk variabel penggunaan smartphone dan penggunaan e-learning terhadap motivasi belajar siswa pada mata pelajaran kearsipan kelas $\mathrm{X}$ OTKP di SMKS Krian 2 Sidoarjo sebagai berikut: 1) Uji-t

$$
\mathrm{Y}=72.958+0.212 \mathrm{X}_{1}+0.329 \mathrm{X}_{2}
$$

Uji-t digunakan untuk mengetahui pengaruh variabel bebas terhadap varaibel terikat secara parsial. Hasil uji-t dapat dilihat pada penggunaan smartphone $\left(\mathrm{X}_{1}\right)$ tidak berpengaruh signifikan terhadap motivasi belajar siswa dengan nilai sig. $0.206>0.05$ dan t-hitung $1.275<\mathrm{t}$-tabel 1.988 yang artinya hipotesis pertama ditolak. Adapun hasil uji-t pada penggunaan e-learning $\left(\mathrm{X}_{2}\right)$ berpengaruh signifikan terhadap motivasi belajar siswa dengan nilai sig. $0.044<0.05$ dan thitung $2.048>$ t-tabel 1.988 yang artinya hipotesis kedua diterima.

2) Uji-F

Hasil uji-F dalam penelitian ini dapat dilihat pada penggunaan smartphone $\left(\mathrm{X}_{1}\right)$ dan penggunaan e-learning $\left(\mathrm{X}_{2}\right)$ secara simultan berpengaruh signifikan terhadap motivasi belajar siswa dengan nilai sig. $0.006<0.05$ dan F-hitung $5.381>$ F-tabel 3.11 yang artinya hipotesis ketiga diterima. Nilai koefisien determinasi pada kolom $R$ Square menunjukkan nilai sebesar 0.115 . Hal ini berarti variabel penggunaan smartphone dan variabel penggunaan e-learning memberikan pengaruh terhadap motivasi belajar siswa sebesar $11.5 \%$. Sedangkan $88.5 \%$ dipengaruhi variabel lain di luar penelitian ini.
Pengaruh Penggunaan Smartphone terhadap Motivasi Belajar Siswa pada Mata Pelajaran Kearsipan Kelas X OTKP di SMKS Krian 2 Sidoarjo

Berdasarkan hasil uji-t diketahui bahwa thitung $1.275<\mathrm{t}$-tabel 1.988 dan nilai signifikansi $0.206>0.05$ maka $\mathrm{H}_{1}$ dinyatakan ditolak, sehingga penggunaan smartphone tidak berpengaruh signifikan terhadap motivasi belajar siswa pada mata pelajaran kearsipan kelas X OTKP di SMKS Krian 2 Sidoarjo. Penelitian ini sesuai dengan penelitian Luo, Kao, \& Liao (2019) yang menyatakan bahwa terdapat perbedaan yang signifikan dari penggunaan smartphone, sehingga secara signifikan memiliki motivasi belajar mahasiswa rendah. Selanjutnya, penelitian Pebriani (2019) mengungkapkan bahwa tidak ada hubungan yang bermakna antara penggunaan smartphone dengan motivasi belajar mahasiswa DIII Keperawatan. Namun hasil penelitian ini bertolak belakang dengan hasil penelitian yang dilakukan oleh Frafitasari (2018) yang menjelaskan bahwa terdapat hubungan antara penggunaan aplikasi smartphone dengan motivasi belajar pada mahasiswa kebidanan semester 5 di Stikes Surya Mitra Husada Kediri. Penelitian Narpati, Handayani, \& Bukhari (2019) menyatakan bahwa ada pengaruh positif yang signifikan antara penggunaan smartphone terhadap motivasi belajar mahasiswa. Smith, et al (2019) juga mengatakan bahwa smartphone tidak mengurangi motivasi siswa dan harus dipertimbangkan apabila terdapat pembelajaran di kelas agar sesuai dengan peraturan yang ditetapkan. 
Adanya hasil penelitian tersebut merujuk pada kondisi yang berada di lapangan berdasarkan hasil wawancara bersama guru mata pelajaran kearsipan yaitu smartphone yang dimiliki siswa mayoritas memiliki kapasitas yang rendah, kecepatan akses yang terbatas dan beberapa kekurangan lain sehingga kurang mendukung untuk diterapkan secara berkala. Penggunaan smartphone belum dapat diterima siswa dengan baik pada mata pelajaran kearsipan kelas X OTKP di SMKS Krian 2 Sidoarjo. Hal ini dapat dilihat dari siswa cenderung kurang senang membaca materi melalui smartphone karena tidak semua siswa memiliki smartphone yang mampu digunakan secara optimal. Siswa kurang mampu mengembangkan budaya literasi digital terutama pada saat pembelajaran kearsipan. Siswa lebih senang membaca buku secara langsung dibandingkan smartphone. Siswa cenderung kurang fokus pada saat membaca serta memahami materi menggunakan smartphone dan konsentrasi mereka menjadi terganggu apabila ada notifikasi lain maupun kegaduhan di lingkungan sekitar mereka. Selanjutnya, yang berkaitan dengan penggunaan waktu untuk membaca materi menggunakan smartphone siswa juga menggunakannya untuk mengakses aplikasi yang menurut mereka lebih menarik sehingga menimbulkan rasa ketergantungan yang tinggi. Siswa juga mudah mengantuk dengan membaca menggunakan smartphone dikarenakan jenuh dan berpengaruh terhadap kelelahan pada mata. Sehingga penggunaan smartphone dalam pembelajaran kearsipan belum dilakukan dengan optimal oleh siswa.

\section{Pengaruh Penggunaan E-learning terhadap Motivasi Belajar Siswa pada Mata Pelajaran Kearsipan Kelas X OTKP di SMKS Krian 2 Sidoarjo}

Berdasarkan hasil uji-t diketahui bahwa thitung $2.048>$ t-tabel 1.988 dan nilai signifikansi $0,044<0,05$ maka $\mathrm{H}_{2}$ dinyatakan diterima, sehingga penggunaan e-learning berpengaruh signifikan terhadap motivasi belajar siswa pada mata pelajaran kearsipan kelas X OTKP di SMKS Krian 2 Sidoarjo. Penelitian ini sesuai dengan penelitian Aurora \& Effendi (2019) yang menyampaikan bahwa terdapat hubungan antara penggunaan e-learning dengan motivasi belajar mahasiswa. Penelitian dari Suwastika (2018) mengatakan bahwa e-learning mempengaruhi motivasi belajar mahasiswa STIKOM Bali. Sari \& Sulisworo (2019) dalam penelitiannya menyatakan bahwa $e$-learning menjadi akses yang mudah dalam pembelajaran dan banyak hal baru yang diperoleh pada saat e-learning sehingga dapat memotivasi peserta didik dalam belajar. Lin, Chen, \& Liu (2017) mengungkapkan bahwa pembelajaran digital berpengaruh positif terhadap motivasi belajar dan hasil belajar daripada pembelajaran tradisional. Penelitian Alwie \& Sa'diyah (2019) juga menunjukkan bahwa terdapat pengaruh penggunaan media pembelajaran berbasis website terhadap motivasi belajar siswa di MAN 1 Bogor.

Berdasarkan fakta yang terdapat di lapangan bahwa e-learning yang biasa digunakan dalam pembelajaran kearsipan adalah edmodo dan whatsapp grup, dimana aplikasi tersebut sangat mudah diakses serta dipahami oleh guru dan siswa sehingga dapat menunjang kelancaran pembelajaran secara virtual. Penggunaan $e$ learning dapat diterima siswa dengan baik pada mata pelajaran kearsipan kelas X OTKP di SMKS Krian 2 Sidoarjo. Hal ini dapat dilihat dari siswa lebih mudah mengakses materi dan latihan soal melalui e-learning. E-learning memudahkan siswa dalam pengerjaan dan pengumpulan tugas. Hal tersebut membuat siswa cenderung sering menggunakan e-learning dalam proses pembelajaran daring pada mata pelajaran kearsipan terutama dalam kondisi pandemi seperti ini. Penggunaan e-learning dapat membantu kelancaran dalam proses pembelajaran online sehingga siswa memiliki motivasi yang tinggi pada saat menggunakan e-learning dalam kegiatan pembelajaran daring pada mata pelajaran kearsipan. Siswa memiliki ketertarikan menggunakan e-learning pada saat pembelajaran daring karena e-learning memiliki fitur-fitur yang sesuai dengan kebutuhan dan bermanfaat untuk pembelajaran. E-learning membantu siswa dapat berdiskusi dengan mudah. Selain itu, e-learning juga membantu kelancaran komunikasi antara guru dengan siswa. Sehingga penggunaan $e$ learning dalam pembelajaran kearsipan sudah dilakukan dengan baik oleh siswa. 
Pengaruh Penggunaan Smartphone dan Penggunaan E-learning terhadap Motivasi Belajar Siswa pada Mata Pelajaran Kearsipan Kelas X OTKP di SMKS Krian 2 Sidoarjo

Berdasarkan hasil uji-F diketahui bahwa F-hitung 5,381 > F-tabel 3.11 dan nilai signifikansi $0.006<0.05$ maka $\mathrm{H}_{3}$ dinyatakan diterima, sehingga penggunaan smartphone dan penggunaan e-learning berpengaruh signifikan terhadap motivasi belajar siswa pada mata pelajaran kearsipan kelas X OTKP di SMKS Krian 2 Sidoarjo. Penelitian ini sesuai dengan penelitian Larasati \& Nikmah (2020) yang menyatakan bahwa penggunaan smartphone dan pemanfaatan e-learning secara simultan berpengaruh positif terhadap motivasi belajar pada pelaksanaan on the job training peserta didik kelas XI OTKP SMKN 10 Surabaya. Penelitian Moh (2015) menyampaikan bahwa terdapat pengaruh yang positif dari pembelajaran menggunakan smartphone dan mobile learning terhadap motivasi. Penelitian Riyanti \& Rusdi (2018) menyatakan bahwa smartphone juga bisa diterapkan melalui aplikasi mobile game based learning dan hasil penelitian menunjukkan bahwa penggunaan game edukasi smartphone memberikan pengaruh yang signifikan terhadap hasil belajar dan motivasi belajar mahasiswa pendidikan biologi STKIP YAPIM Maros. Selanjutnya, Khaeriyah \& Mahmud (2017) mengatakan bahwa intensitas penggunaan smartphone dan pemanfaatan internet sebagai sumber belajar berpengaruh secara positif dan signifikan terhadap motivasi belajar siswa kelas X1 IPS SMA Negeri di Pemalang Kota. Muskita (2018) juga mengungkapkan bahwa pemanfaatan internet menggunakan media handphone mempunyai pengaruh yang signifikan terhadap motivasi belajar mahasiswa baru Universitas Katolik Widya Mandala Madiun.

Berdasarkan pada kondisi yang ada di lapangan, siswa mampu menggunakan smartphone dan e-learning secara baik dalam pembelajaran kearsipan, meskipun memiliki kendala pada smartphone yang dimiliki tidak membuat siswa menjadi putus asa dan guru juga selalu memberikan arahan serta memotivasi siswa sehingga mereka memiliki motivasi yang cukup tinggi dalam pelaksanaan pembelajaran secara daring. Penggunaan smartphone dan penggunaan e-learning secara bersama-sama dapat diterima siswa dengan baik pada mata pelajaran kearsipan kelas X OTKP di SMKS Krian 2 Sidoarjo. Hal ini dapat dilihat dari siswa cenderung tertantang dengan adanya materi yang cukup sulit dan memiliki target dalam menyelesaikan penugasan pada penggunaan smartphone dan penggunaan $e$ learning. Siswa memiliki rasa keingintahuan yang cukup tinggi dengan aktif bertanya tentang materi maupun penugasan apabila ada yang kurang dimengerti pada saat pembelajaran melalui $e$ learning. Guru memberikan reward berupa tambahan poin pada siswa yang aktif bertanya dan menjawab maupun menyampaikan gagasan ataupun pendapat. Guru memberikan pujian pada siswa yang hadir tepat waktu sebelum pembelajaran dimulai. Siswa juga selalu memperhatikan penjelasan dari guru dan berusaha mengerjakan tugas tepat waktu, tertib aturan, dan disiplin waktu pada saat menggunakan smartphone dan mengikuti pembelajaran $e$ learning. Sehingga penggunaan smartphone dan penggunaan e-learning mampu memberikan pengaruh positif terhadap motivasi belajar siswa baik secara intrinsik maupun ekstrinsik pada mata pelajaran kearsipan.

\section{SIMPULAN DAN REKOMENDASI}

Berdasarkan hasil dan pembahasan, maka dapat disimpulkan sebagai berikut: 1) tidak terdapat pengaruh signifikan penggunaan smartphone terhadap motivasi belajar siswa pada mata pelajaran kearsipan kelas X OTKP di SMKS Krian 2 Sidoarjo, sehingga $\mathrm{H}_{1}$ ditolak; 2) terdapat pengaruh signifikan penggunaan e-learning terhadap motivasi belajar siswa pada mata pelajaran kearsipan kelas X OTKP di SMKS Krian 2 Sidoarjo, sehingga $\mathrm{H}_{2}$ diterima; 3) terdapat pengaruh signifikan penggunaan smartphone dan penggunaan e-learning terhadap motivasi belajar siswa pada mata pelajaran kearsipan kelas X OTKP di SMKS Krian 2 Sidoarjo, sehingga $\mathrm{H}_{3}$ diterima.

Adapun saran yang dapat diberikan oleh peneliti, yaitu: 1) adanya jadwal untuk 
pembelajaran tatap muka secara bergantian di sekolah terutama pada saat mata pelajaran kearsipan yang bersifat praktik agar guru lebih mudah memantau pemahaman siswa dan siswa dapat melakukan praktik secara langsung; 2) untuk penelitian selanjutnya disarankan menambah variabel dengan menggunakan sampel dan populasi lain selain siswa kelas X OTKP di SMKS Krian 2 Sidoarjo.

\section{DAFTAR PUSTAKA}

Adjei, N. D. (2019). The Use And Effect Of Smartphones In Students' Learning Activities: Evidence From The University Of Ghana, Legon. Library Philosophy and Practice, $1-37$. https://digitalcommons.unl.edu/cgi/viewc ontent.cgi article $=6260 \&$ context $=$ libphilp rac

Aini, Q., Dhaniarti, I., \& Khoirunisa, A. (2019). Effects of iLearning Media on Student Learning Motivation. Jurnal ATM (APTISI Transactions on Management), 3(1), 1-12. http://garuda.ristekbrin.go.id/documents/d etail/904579

Alwie, \& Sa'diyah, M. (2019). Pengaruh Penggunaan Media Pembelajaran Berbasis Website Terhadap Motivasi Belajar Siswa Di MAN 1 Kota Bogor. Jurnal Penelitian Pendidikan Humaniora, 4(2), 547-553. https://jurnal-

lp2m.umnaw.ac.id/index.php/JP2SH/articl e/view/338

Anugrahana, A. (2020). Hambatan, Solusi dan Harapan: Pembelajaran Daring Selama Masa Pandemi Covid-19 Oleh Guru Sekolah Dasar. Jurnal Scholaria, 10(3), 282-289.

Anurrahman. (2014). Belajar dan Pembelajaran. Bandung: Alfabeta.

Ardyansyah, S. S. (2019). Pengaruh Penggunaan Gadget Terhadap Motivasi Belajar Bagi Mahasiswa Program Studi Teknik Informatika ITN Malang. Jurnal Valtech, 2(2), 160-165. https://ejournal.itn.ac.id/index.php/valtech /article/view/1907

Aurora, A., \& Effendi, H. (2019). Pengaruh Penggunaan Media Pembelajaran E- learning terhadap Motivasi Belajar Mahasiswa di Universitas Negeri Padang. JTEV (Jurnal Teknik Elektro Dan Vokasional), 05(02), 11-16. http://ejournal.unp.ac.id/index.php/jtev/in dex

Dalimunthe, D. A. (2020). The Effect of Using ELearning Media On Students' Learning Motivation. Jurnal Pendidikan Dan Keluarga, 12(02), 114-120. https://doi.org/https://doi.org/10.24036/jp k/vol12-iss02/829

Etnanta, Y. C., \& Irhandayaningsih, A. (2017). Pengaruh Penggunaan Smartphone Terhadap Minat Baca Siswa SMA Negeri 1 Semarang. Jurnal Ilmu Perpustakaan, $6(1)$, 371-380. https://ejournal3.undip.ac.id/index.php/jip /article/view/23095

Festiawan, R. (2020). Belajar dan Pendekatan Pembelajaran. Jawa Tengah: Universitas Jenderal Soedirman.

Fitria, D., Saifudin, S., \& Zaman, B. (2020). The Effect of E-Learning on Learning Motivation in Islamic Religious Education Subjects. HALAQA: Islamic Education Journal, 4(2), 113-124. https://doi.org/10.21070/halaqa.v4i2.984

Frafitasari, D. Y. (2018). Pengaruh Penggunaan Aplikasi Smartphone Terhadap Motivasi Belajar Mahasiswa D3 Kebidanan Semester 5 Di STIKES Surya Mitra Husada Kediri. Jurnal IMJ: Indonesian Midwifery Journal, 2(1), 60-71. http://jurnal.umt.ac.id/index.php/imj/articl e/view/3053

Hamidah, R., Permata, C. I. H., Surindra, B., \& Irmayanti, E. (2020). Pengaruh Optimalis Pembelajaran Online Dan Partisipasi Mahasiswa Terhadap Motivasi Belajar Online Mahasiswa Tingkat II Pendidikan Ekonomi Universitas Nusantara PGRI Kediri. Seminar Nasional Manajemen, Ekonomi Dan Akuntansi Fakultas Ekonomi Dan Bisnis UNP Kediri, hlm. 447-452. Fakultas Ekonomi dan Bisnis UNP Kediri. https://proceeding.unpkediri.ac.id/index.p $\mathrm{hp} /$ senmea/article/view/287 
Hanafy, M. S. (2014). Konsep Belajar Dan Pembelajaran. Lentera Pendidikan : Jurnal Ilmu Tarbiyah Dan Keguruan, 17(1), $66-79$. https://doi.org/10.24252/lp.2014v17n1a5

Harandi, S. R. (2015). Effects of E-Learning on Students ' Motivation. Procedia Social and Behavioral Sciences, 181, 423-430. https://doi.org/10.1016/j.sbspro.2015.04.9 05

Hikmawan, T., \& Sarino, A. (2018). Pemanfaatan Media Pembelajaran Berbasis Edmodo Terhadap Motivasi Belajar Siswa Sekolah Menengah Kejuruan ( The Impact of Electronic Media Base Edmodo on Student ' Motivation Learning at Vocational High School ). Jurnal Pendidikan Manajemen Perkantoran, 3(1), 79-86. https://doi.org/10.17509/jpm.v3i1.9459

Jayatri, F., Ayuningtyas, T., \& Andriani, C. D. (2019). Penggunaan E-Learning sebagai Media Penunjang Mutu Pembelajaran di Prodi Pendidikan Ekonomi STKIP PGRI Lumajang. Procedings of the ICECRS, hlm. 265-272. Pendidikan Ekonomi STKIP PGRI Lumajang. https://doi.org/10.21070/picecrs.v2i1.239 2

Khaeriyah, \& Mahmud, A. (2017). Pengaruh Intensitas Penggunaan Smartphone Dan Pemanfaatan Internet Terhadap Motivasi Belajar Dan Hasil Belajar Ekonomi. Economic Education Analysis Journal, 6(1), 140-149. http://journal.unnes.ac.id/sju/index.php/ee aj

Kuswinarko, M., \& Kusumah, I. H. (2017). Eksplorasi Motivasi Belajar Siswa SMK Dalam Mengikuti Mata Pelajaran Pekerjaan Dasar Teknik Otomotif. Journal of Mechanical Engineering Education, 4(1), 96-100. https://ejournal.upi.edu/index.php/jmee/ar ticle/view/7447

Larasati, \& Nikmah, C. (2020). Pengaruh Penggunaan Smartphone dan E-learning Terhadap Motivasi Belajar Dalam Masa Pelatihan Kerja ( The Effect of Smart phone Use and E-learning on Learning
Motivation in On The Job Training ). Jurnal Pendidikan Manajemen Perkantoran, 5(2), 214-233. https://doi.org/10.17509/jpm.v4i2.18008

Lin, M., Chen, H., \& Liu, K. (2017). A Study of the Effects of Digital Learning on Learning Motivation and Learning Outcome. EURASIA Journal of Mathematics Science and Technology Education, 13(7), 35533564.

https://doi.org/10.12973/eurasia.2017.007 $44 \mathrm{a}$

Luo, Y., Kao, C., \& Liao, C. (2019). Impact of Smartphone Usage on Physical Education Scores and Learning Motivation. International Journal of Learning and Teaching, 5(1), 50-53. https://doi.org/10.18178/ijlt.5.1.50-53

Mahmud, H., \& Iqbal. (2019). Pembelajaran Berbasis Edmodo Dan Motivasi Belajar Peserta Didik Di SMKN 2 Palopo. Journal of Islamic Education Management, 4(1), 49-60.

https://ejournal.iainpalopo.ac.id/index.php /kelola

Maknuni, J. (2020). Pengaruh Media Belajar Smartphone Terhadap Belajar Siswa Di Era Pandemi ( The Influence of Smartphone Learning Media on Student Learning in The Era Pandemi. Indonesisan Education Administration and Leadership Journal (IDEAL), 02(02), 94-106. https://onlinejournal.unja.ac.id/index.php/IDEAL

Mintarsih, H. (2020). Pemanfaatan Aplikasi Quizizz Berbasis Smartphone Dalam Meningkatkan Motivasi Belajar Siswa SMK. Prociding Seminar Nasional Pendidikan, Universitas Sarjanawiyata Tamansiswa Yogyakarta. https://jurnal.ustjogja.ac.id

Moh, C. (2015). Students Acceptance of Using Smartphone in a Mobile Learning Context. Educational Research and Reviews, 10(14), 1937-1942. https://doi.org/10.5897/err2015.2229

Muskita, S. M. (2018). Pengaruh Pemanfaatan Internet Dengan Media Handphone Terhadap Motivasi Belajar Mahasiswa 
Jurnal PAJAR (Pendidikan dan Pengajaran)

Volume 5 Nomor 6 November | ISSN Cetak : 2580 - 8435 | ISSN Online : 2614 - 1337

DOI : http://dx.doi.org/10.33578/pjr.v5i6.8421

Baru Universitas Katolik Widya Mandala Madiun Tahun Akademis 2015 / 2016. Prosiding SNBK (Seminar Nasional Bimbingan Dan Konseling), hlm. 361366. FKIP Universitas Katolik Widya Mandala, Madiun. http://prosiding.unipma.ac.id/index.php/S NBK/index

Narpati, B., Handayani, M., \& Bukhari, E. (2019). Aplikasi Belajar Berbasis Digital Dapat Meningkatkan Motivasi Belajar Mahasiswa. Jurnal Komunitas: Jurnal Pengabdian Kepada Masyarakat, 2(1), 87-93.

https://doi.org/10.31334/jks.v2i2.478

Nurhasanah, S. (2017). Praktikum Statistika 2 Untuk Ekonomi dan Bisnis Apllikasi dengan MS Excel dan SPSS. Jakarta: Salemba Empat.

Pane, A., \& Dasopang, M. D. (2017). Belajar dan Pembelajaran. FITRAH Jurnal Kajian Ilmu-Ilmu Keislaman, 03(2), 333-352. jurnal.iainpadangsidimpuan.ac.id/index.php/F

Pebriani, S. H. (2019). Hubungan Penggunaan Smartphone Dengan Motivasi Belajar Pada Mahasiswa DIII Keperawatan. Babul Ilmi_Jurnal Ilmiah Multi Science Kesehatan, 10(2), 213-224. http://jurnal.stikes-aisyiyahpalembang.ac.id/index.php/Kep/index

Puasanti, S., \& Shanti, L. P. (2019). Hubungan Antara Intensitas Penggunaan Gadget Dengan Motivasi Belajar Siswa SMK Tunas Harapan Pati. Konferensi Ilmiah Mahasiswa UNISSULA (KIMU) 2, 13401347. Universitas Islam Sultan Agung Semarang.

http://repository.unissula.ac.id/15881/

Rikizaputra, \& Sulastri, H. (2020). Pengaruh ELearning Dengan Google Classroom Terhadap Hasil Dan Motivasi Belajar Biologi Siswa. Jurnal Pendidikan, 11(1), 106-118.

http://journal.unilak.ac.id/index.php/lectur a/article/view/3760

Riyanti, R., \& Rusdi, H. (2018). Efektivitas Penggunaan Game Edukasi Smartphone Terhadap Hasil Belajar Dan Motivasi
Belajar Mahasiswa Pendidikan Biologi STKIP YAPIM MAROS. Jurnal Ilmiah Pena, 1(2), 21-28. http://ojs.stkippi.ac.id/index.php/jip/articl e/view/148

Sandybayev, A. (2020). The Impact of E- Learning Technologies on Student's Motivation: Student Centered Interaction in Business Education. International Journal of Research in Tourism and Hospitality (IJRTH), 6(1), 16-24. http://www.academia.edu/download/6210 3772/220200214-29470-13bbc28.pdf

Santoso, I. H. (2019). Statistik II (Untuk Ilmu Sosial dan Ekonomi). Surabaya: UWKS PRESS.

Sari, I. F., \& Sulisworo, D. (2019). E-Learning in English Language Learning for Increasing Students's Motivation. Advances in Social Science, Education Adn Humanities Research, hlm. 660-664. https://www.atlantispress.com/proceedings/iccd$19 / 125919176$

Setiawan, M. A. (2017). Belajar dan pembelajaran. Palangka Raya: Uwais Inspirasi Indonesia.

Smith, H. E., Blackburn, J. J., Stair, K. S., \& Burnett, M. F. (2019). Determining the Effects of the Smartphone as a Learning Tool on the Motivation of School-Based Agricultural Education Students in Louisiana. Journal of Agricultural Education, 60(3), 141-154. https://doi.org/https://doi.org/10.5032/jae/ 2019/03141

Srinadi, N. L. P. (2015). Analisis Pengaruh Penggunaan Teknologi Informasi Sebagai Media Pembelajaran Terhadap Motivasi Belajar Siswa. Prosiding Konferensi Nasional Sistem \& Informatika, 9-10. STMIK STIKOM Bali. http://ejournal.stikom-

bali.ac.id/index.php/knsi/article/view/556

Sugiyono. (2019). Metode Penelitian Kuantitatif Kualitatif dan $R \& D$. Yogyakarta: Alfabeta.

Sujiwo, D. A. C., \& A'yun, Q. (2020). Pengaruh Pemanfaatan E-learning Terhadap 
Jurnal PAJAR (Pendidikan dan Pengajaran)

Volume 5 Nomor 6 November | ISSN Cetak : 2580 - 8435| |ISSN Online : 2614 - 1337

DOI : http://dx.doi.org/10.33578/pjr.v5i6.8421

Motivasi Belajar Mahasiswa. JUSTINDO

(Jurnal Sistem \& Teknologi Informasi

Indonesia), 5(2), 53-59.

http://jurnal.unmuhjember.ac.id/index.php

/JUSTINDO/article/view/3469

Suwastika, I. W. K. (2018). Pengaruh E-Learning Sebagai Salah Satu Media Pembelajaran Berbasis Teknologi Informasi Terhadap Motivasi Belajar Mahasiswa. Jurnal Sistem Dan Infromatika, 13(1), 1-5. http://jsi.stikom-

bali.ac.id/index.php/jsi/article/view/185

Thohuroh, \& Puspasari, D. (2018). Pengembangan Media Pembelajaran Permainan Kartu YuGi-Oh pada Kompetensi Dasar Menjelaskan Sistem Kearsipan. Jupeko (Jurnal Pendidikan Ekonomi), 3(1), 1629.

https://jurnal.stkippgritulungagung.ac.id/i ndex.php/jupeko/article/view/619 